\title{
Resource-use and partial-budget analysis of a transition to reduced-input and organic practices and direct marketing: A student-farm case study
}

\author{
Sean Clark * \\ Berea College
}

Submitted May 27, 2013 / Revised August 11, September 29, and November 26, 2013 / Accepted November 26, 2013 /

Published online February 27, 2014

Citation: Clark, S. (2014). Resource-use and partial-budget analysis of a transition to reduced-input and organic practices and direct marketing: A student-farm case study. Journal of Agriculture, Food Systems, and Community Development, 4(2), 113-130. http://dx.doi.org/10.5304/jafscd.2014.042.005

Copyright (C) 2014 by New Leaf Associates, Inc.

\begin{abstract}
The Berea College student farm undertook a transition to alternative practices in an effort to improve the sustainability of its operations, which included an expansion of organic crop production, a transition to reduced-input cattle and hog production, and a shift toward local marketing and sales, particularly of value-added products. The changes, developed and planned by students, staff and faculty in 2007 , were implemented in 20082009 and fully in place by 2010 . The plan required a reduction in livestock herd sizes, creating less dependence on purchased off-farm inputs, such as livestock feedstuffs and fertilizers for growing animal feed-crops. Third-party certifications, including USDA Certified Organic and Animal Welfare Approved, facilitated access to price premiums and new markets. Selling more meat and
\end{abstract}

* Sean Clark, Agriculture and Natural Resources Program, Berea College, Berea, Kentucky 40404 USA; +1-859-9853402; sean clark@,berea.edu fewer live animals resulted in financial gains for the livestock enterprises, but the greatest returns were generated through organic horticultural production. Questions remain about the environmental, social, and animal-welfare tradeoffs from the transition, but it clearly resulted in financial improvements and reduced dependence on off-farm inputs. This paper quantitatively documents the effects of the initiatives and illustrates the interdependencies among the changes to the whole-farm system.

\section{Keywords}

direct marketing, grass-finished beef, low-input farming, organic farming, outdoor hog production, student farm, value-added

\section{Introduction}

Transitioning to alternative production, marketing, and sales practices for improved sustainability may bring financial risk as well as potential long-term benefits to farms. Economic incentives, such as 
price premiums and stronger market demand, may exist for products grown or raised according to particular rules, such as certified organic or humanely raised. Shorter supply chains also offer opportunities for adding value, in part by communicating with customers the story behind the products. But during transition periods, which may last for several years, there are often no premiums, markets may be difficult to find or establish that pay any premium, and actual conditions and outcomes for the farm and/or market may differ from those of controlled field experiments or modeling exercises, which are often important sources of technical information to producers. Farm case studies have value in providing insights into how real-world complexity and unique local conditions can affect how transitions play out and whether predictions and expectations are realized. Student farms, operated on increasing numbers of college and university campuses, provide venues for such case studies since they often use unconventional practices, have many individuals participating and making observations, maintain thorough management records, are not rigorously controlled or nar- rowly focused on single variables like replicated field experiments, and can sometimes take risks that private, family farms cannot afford (Sayre \& Clark, 2011). There are drawbacks as well, such as distinguishing between educational activities and production work, and the fact that such farms may be protected from land payments, taxes, and other costs that private farms face.

This paper reports on the impetus, planning, implementation, and results of an effort to address concerns about sustainability on the Berea College Farm, the experiential-learning laboratory of the college's academic program in agriculture and natural resources. The implementation of the changes in 2008 and 2009 included an expansion of organic crop production to partially replace conventional production, a transition to reduced-input livestock production, and a greater emphasis on local marketing and sales with a particular focus on adding value to raw farm products (table 1). The effects of the initiatives on the farm's dependency on offfarm resources and its financial performance, as well as the mutual dependencies among the three initiatives, are examined.

Table 1. Initiatives Implemented on the Berea College Farm to Address Sustainability Concerns

\begin{tabular}{|c|c|c|}
\hline Initiative & Main Issues Targeted & Expected Performance Outcomes \\
\hline $\begin{array}{l}\text { Expansion of organic } \\
\text { crop production }\end{array}$ & $\begin{array}{l}\text { Potential negative environmental and health } \\
\text { effects of fertilizers and pesticides }\end{array}$ & $\begin{array}{l}\text { - Reduce risk of water and air pollution } \\
\text { - Reduce risk to human health } \\
\text { - Receive premiums for organic foods } \\
\text { - Reduce material input costs }\end{array}$ \\
\hline $\begin{array}{l}\text { Transition to outdoor } \\
\text { hog production and } \\
\text { grass-finishing cattle }\end{array}$ & $\begin{array}{l}\text { - Small-scale confinement hog production } \\
\text { unprofitable and many consider it inhumane } \\
\text { - Feeding ruminants grain is unnecessary and } \\
\text { energetically expensive; pasture can be } \\
\text { produced with few inputs }\end{array}$ & $\begin{array}{l}\text { - Recycle soil nutrients (especially nitrogen) } \\
\text { - Reduce nonrenewable energy use } \\
\text { - Reduce capital costs of hog production } \\
\text { - Model a more viable option for small farmers } \\
\text { - Eliminate subtherapeutic antibiotic use in feed } \\
\text { - Improve animal welfare } \\
\text { - Reduce environmental impact by feeding cattle } \\
\text { - Rrasses and forages rather than grain } \\
\text { - Reduce feed costs } \\
\text { - Reduce need for corn grain }\end{array}$ \\
\hline $\begin{array}{l}\text { Shift toward local } \\
\text { marketing and sales, } \\
\text { particularly of value- } \\
\text { added products }\end{array}$ & $\begin{array}{l}\text { Difficulty in achieving small-farm financial } \\
\text { viability because commodity production is } \\
\text { unprofitable for small to medium-sized farms }\end{array}$ & $\begin{array}{l}\text { - Add value to lower-value commodities } \\
\text { - Develop market demand for local, artisanal } \\
\text { food products } \\
\text { - Reduce "food miles" } \\
\text { - Increase local food availability and diversity } \\
\text { - Increase consumer understanding of } \\
\text { agriculture }\end{array}$ \\
\hline
\end{tabular}




\section{Methods}

This analysis is based on farm records collected throughout the implementation of the initiatives. The records included all expenses for material inputs and services, sales of all crop and livestock products to different markets, the number of acres allocated to various crops (field, forage, and horticultural) and livestock species, and the amount of acreage under organic management during the transition period. Interviews with the farm manager helped provide context and explanations for quantitative data.

Due to the nature of the college's educational labor program it was not feasible to accurately record the labor inputs for each enterprise because of the inability to clearly delineate between educational and production activities. However, the total amount of labor on the whole farm was constant during the study period. There were approximately 45 students working on the farm for 10 hours per week during each academic year and 6 to 8 students working full-time during each summer. More than 100 different students worked on the farm at some point during the study period. Because students had to be trained and instructed by staff before safely using equipment or carrying out new tasks, distinguishing between the amount of time spent learning and spent "doing" was practically impossible, which changed not only seasonally but often daily.

Thus, partial budgets were constructed for individual enterprises and the whole farm that included all material input purchases and product sales, but not labor inputs. Partial-budget analyses are used to compare alternative options for a farm business, like adopting a new technology, changing enterprises, or modifying production practices (Roth \& Hyde, 2002). Aspects of the farm budget that remain unchanged (in this case, labor inputs) can be left out of the analysis. The goal of this analysis was to assess the trajectory of the wholefarm system with respect to its dependence on offfarm inputs and financial performance as measured by gross income minus input costs.

\section{The Farm Before Transition}

The Berea College Farm at Berea College, located in Berea, Kentucky, a city of 13,763 people (U.S. Census Bureau, n.d.) and established in the 1870s, is one of the oldest continuously operating student educational farms in the U.S. (figure 1). Like most student farms, it had modest beginnings which first took the form of student initiatives and learning projects, but developed over decades into multiple, integrated, and commercially viable enterprises on hundreds of acres of land around the campus and city of Berea. The farm's enterprises provided students with learning and work opportunities and

\section{Figure 1. Location of the Berea College and its Student Farm}

The Berea College Farm is in Berea, Kentucky, in a region known as the Knobs, between the Bluegrass and the Appalachian foothills (also known as the Eastern Kentucky Coal Fields)

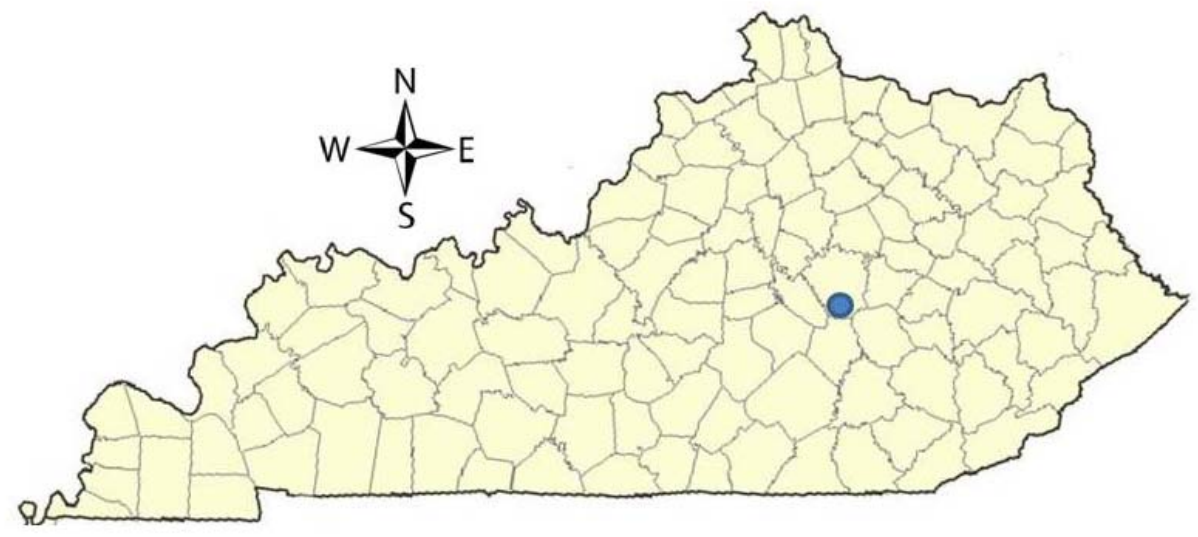

generated some income to support the college. The farm also became an important source of some food products for the campus dining hall and the surrounding community. As is still the case today, students were involved in all aspects of the farm's daily operations throughout the 
year. The composition of the farm's enterprises and their relative scale have changed over the farm's 140-year history in response to sociopolitico-economic factors, technological changes, student and faculty interest, and available expertise and resources, but have included beef cattle, dairy cattle, sheep, goats, poultry, field crops, and horticultural crops (Clark, 2011).

By the 1990s the farm had closed its dairy and poultry operations, which for decades had produced milk and eggs for local and regional markets. These systems were replaced with conventional meat-livestock production for commodity markets, a reflection of the larger agricultural economy of Kentucky, where over two-thirds of farm gross receipts are for livestock and most of the remainder is for crops like corn and soybean used to feed livestock (USDA National Agricultural Statistics Service [NASS], 2008). At the beginning of the study period most of the student farm's available land — 412 acres (167 ha) — was dedicated to the production of beef cattle, hogs, sheep, or goats and their feed crops. Only about one percent of the farm's land resources was in horticultural crops, including community gardens.

This use of the farm's land not only mirrors Kentucky's agriculture; it is also fairly consistent with land capability classifications according to the USDA soil survey. An analysis of the farm's land resources using a model developed by Holder (2011) to assess Kentucky's human carrying capacity - factoring in land use classification, farmland classification, physiographic description, and flooding frequency — indicated that the most appropriate use for 80 percent of the farm's acreage was hay production and/or pasture. Much of the remaining 20 percent, land considered suitable for annual cropping, was dedicated to corn production to support the farm's three livestock enterprises: (1) hogs; (2) cattle; and (3) goats and sheep.

Production maximization rather than profitability was emphasized, if not as an explicit goal then at least in practice, to demonstrate the practices needed to achieve high productivity in a conventionally managed system. Though some effort was always made to generate sufficient revenues to cover operational costs, financial losses and budget overruns were common in the farm's history. The farm, of course, had no control over market prices or input costs, and production expenses often exceeded livestock commodity values. The losses were partially explained by the scales of the enterprises, which presumably were insufficient to achieve the economy of scale needed for profitability, and the students' lack of experience. But they were also justified as necessary costs for providing students with this practical educational experience. The products of the farm mostly livestock on the hoof and some cash grains and hay - were considered byproducts of this educational program and were dispensed with in the most convenient way possible, even if it came at a loss.

Meat hogs that were produced using a conventional indoor confinement system were sold mostly to the nearest large corporate meatpackers, located over 100 miles $(161 \mathrm{~km})$ away in Louisville. Some hogs were sold locally: meat hogs for home processing and feeder pigs to other farmers when in excess of what the farm could manage. The rations fed to the hogs were produced with the farm's mill using corn produced on-farm, purchased soybean meal, and a premix with minerals, vitamins, and a subtherapeutic concentration of antibiotic. Corn was purchased when needed. Hog waste was flushed into lagoons and periodically sprayed into adjacent pastureland.

The cattle, sheep, and goats were sold mostly at a nearby stockyard, and some as frozen, customprocessed wholes, halves, and quarters to local customers. These few animals would be finished on-farm using a grain-based ration and silage and maintained in a small feedlot or barn. Efforts were made to produce as much feed as possible on-farm by supplying fertilizer and lime to corn, hay, and silage crops at rates recommended by cooperative extension, but when livestock numbers exceeded the farm's feed-production capacity, feed had to be purchased. This production-maximization approach kept the farm at the edge of thoroughly utilizing its land and crop-production capacity and frequently required off-farm feed purchases to make up for shortages.

Though students gained extensive hands-on experience in conventional livestock production 
with this model, they were not privy to financial records and generally did not participate regularly in farm strategic planning and decision-making. The annual farm budget did not include student or staff wages, which were considered an educational cost, but it was expected to cover all nonpersonnel operational expenses with the income generated. These costs included material inputs (fertilizer, fuel, machinery, herbicides, pharmaceuticals, equipment, seed, semen, etc.) and services (veterinary visits, on-site repairs, custom harvesting, etc.). Any income generated in excess of the annual operating costs could be invested into needed infrastructural maintenance or special projects. But in most years some enterprises would lose money and need to be subsidized by other enterprises to ensure that the whole farm would meet its budget expectation or at least come close.

\section{Origin of Change}

By the early 2000s a complete turnover of faculty and staff occurred, largely as a result of retirements and new hires. There was also growing student demand for the farm to offer opportunities to learn and gain work experience in alternative agriculture, such as organic and biointensive systems (Jeavons, 2001). These requests came mostly from students with horticultural interests who saw a disproportionately large allocation of support and resources for livestock production on the farm and wanted larger food-system issues addressed. As a result, several horticulture projects gained support and were implemented, including a food-waste composting project (Clark \& Cavigelli, 2005), a biointensive demonstration area, organic certification of about four acres (1.6 ha) of land for vegetables and fruits, and a 40-share community-supported agriculture (CSA) program.

Following these student-initiated efforts, students were given the opportunity to dedicate more of their weekly work hours to particular farm enterprises by becoming part of an enterprise management team with a faculty or staff mentor. This allowed them to become more engaged with what interested them most and to play a more active role in planning and decision-making. At about the same time, the faculty and staff of the college's Agriculture and Natural Resources department, which was responsible for overseeing the student farm, had delved into an overdue self-study to critically examine, revise, and update its academic program, including the student farm, which serves as its primary laboratory. During the process, which spanned nearly three academic semesters, the philosophical differences among faculty members were evident, but after months of discussion the group was able to agree on two general and overarching goals for the farm:

1. That it serve as a laboratory to provide students with practical learning experiences, and

2. That its enterprises be models of sustainable agricultural production in the region.

Though these left plenty of room for interpretation, all agreed that the farm should be a laboratory to build relevant skills and necessary knowledge for graduates who wanted to pursue farming as a livelihood or work in a career involving food and agriculture in this region, where small, resource-limited farms are the norm. The following four basic elements were established as the criteria for defining what would be meant by "sustainable agricultural production":

1. Environmental: minimizes the negative effects on water, air, soil, energy resources, human health, and ecosystem functions;

2. Economic: is based on sound financial management that results in reasonable and stable profits;

3. Social: creates desirable and safe work that instills a sense of pride and dignity; and

4. Humane: treats livestock with care and provides comfortable conditions during production.

These criteria were not especially precise, original, or innovative, but their inclusion in the selfstudy finally provided a framework for assessing the farm's performance, making decisions, and evaluating new ways of running enterprises to make them more applicable to today's markets. The self-study was finalized and approved by the college's administration in May 2007. 
To implement the goals of the self-study, a visioning and planning workshop was held in the fall semester of 2007, to which all students working on the farm were invited, along with all staff and faculty affiliated with the farm, assuring that all stakeholders were offered the opportunity to be involved with the process. The objective of the event was to assess the farm and develop more specific goals for each of the five enterprises (hogs, beef cattle, goats/sheep, field crops, and horticultural crops). The group of about three dozen students, staff, and faculty contributed to developing short- and long-term goals in a process that emphasized transparency and democratized decision-making, planning, and allocation of resources. Three clusters of interdependent initiatives emerged from the process:

1. Expansion of organic crop production;

2. Transition toward low-input livestock production; and

3. Localization of marketing and sales with an emphasis on value-added products.

These initiatives supported the two overarching farm goals and were consistent with the four criteria defining sustainability, modeling more appropriate practices for small and medium-sized farms in the region. Plans were developed for each initiative and refined through weekly formal discussions among faculty and staff; weekly meetings of the student management teams and their faculty or staff mentor; and an annual visioning and planning workshop to assess progress and adapt to unanticipated events.

This analysis examines the wholefarm performance and focuses on the changes to the cattle, hogs, and horticulture enterprises the three dominant enterprises of the farm based on income and/or use of land resources (table 2). Agronomic crops, including field crops and forages, are not addressed individually since they are regarded as part of the livestock/meat value chains. Any field crops produced as human food on a small scale, including corn, wheat, and dry beans, were included under the horticulture enterprise. The goat/sheep enterprise is also not addressed independently since it played a minor role in supporting the farm financially and few major changes were made to it as a result of these initiatives.

\section{Expansion of Organic Crop Production} Organic crop production typically bases its farm plan on a number of synergistic environmental benefits that take soil, water, air, biodiversity, and human health into consideration (Gomiero, Pimentel, \& Paoletti, 2011). Transitioning a larger portion of the college farm's cropland to organic management was intended to reduce the farm's use of and expenditures on fertilizers and herbicides; provide more flexibility for longer organic horticultural and agronomic crop rotations; generate more revenue by marketing certified organic field crops; open up the possibility for organic livestock production in the future; and improve soil quality over the long term by building soil organic matter. Trade-offs and challenges were expected and research indicated that agronomic crop yields would likely decline, at least for corn and possibly other grains, due to intensified weed competition and less predictable nitrogen availability (Badgley et al., 2007; Cavigelli, Teasdale, \& Conklin, 2008; Clark, Klonsky, Livingston, \& Temple, 1999; Pimentel, Hepperly, Hanson, Douds, \& Seidel, 2005).
Table 2. Berea College Farm Enterprises, Average Percentage of Land Dedicated to Each, and Average Annual Gross Income During the Transition Period, 2007-2012

\begin{tabular}{lccc}
\hline Enterprise & $\begin{array}{c}\text { Percent of farm } \\
\text { acreage }^{\text {a }}\end{array}$ & $\begin{array}{c}\text { Average annual } \\
\text { gross income (\$US) }\end{array}$ & $\begin{array}{c}\text { Average annual gross } \\
\text { income per acre (0.4 ha) }\end{array}$ \\
\hline Hogs & 17 & $\$ 62,000$ & $\$ 868$ \\
\hline Beef cattle & 69 & $\$ 57,000$ & $\$ 197$ \\
\hline Horticulture & 2 & $\$ 40,000$ & $\$ 4,762$ \\
\hline Field crops (sold off-farm) & 6 & $\$ 12,000$ & $\$ 476$ \\
\hline Goats & 6 & $\$ 5,000$ & $\$ 198$ \\
\hline
\end{tabular}

a Total farm acreage is 412 acres (167 ha) 
Figure 2. Acreage of Land Managed Organically of the 412 Available Acres of the Berea College Student Farm, 2006-2012

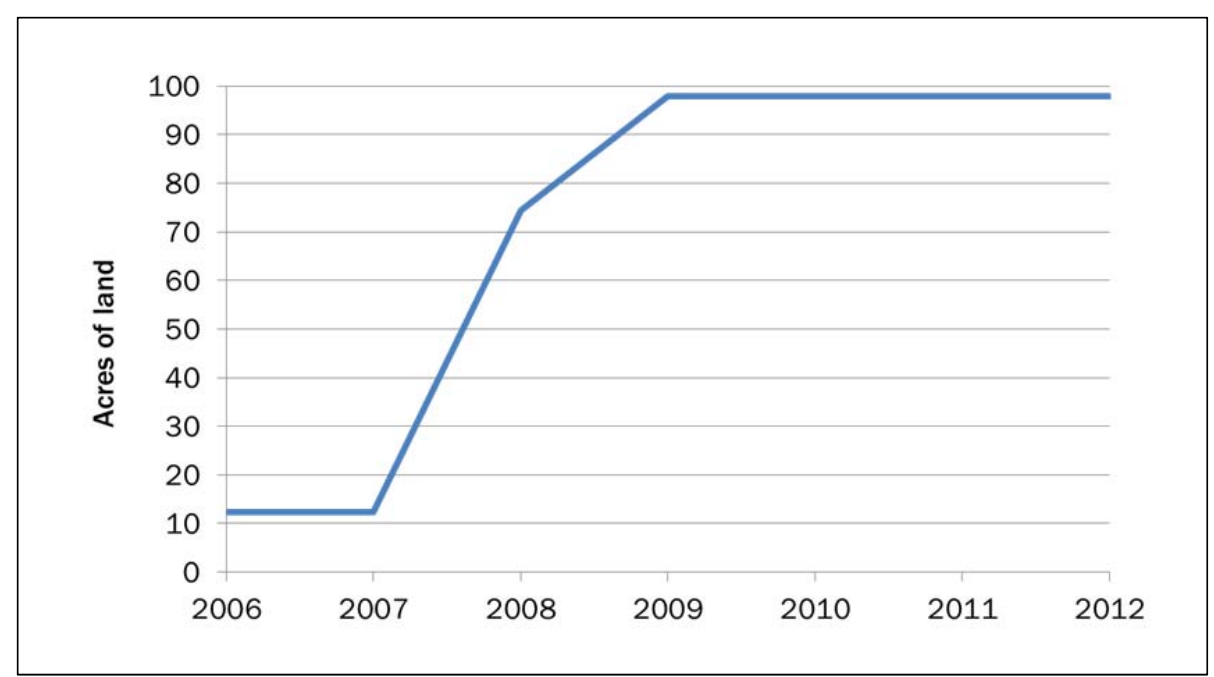

Note: 1 acre $=0.4$ ha

Figure 3. Synthetic Fertilizer Use on the Berea College Student Farm, 2006-2012

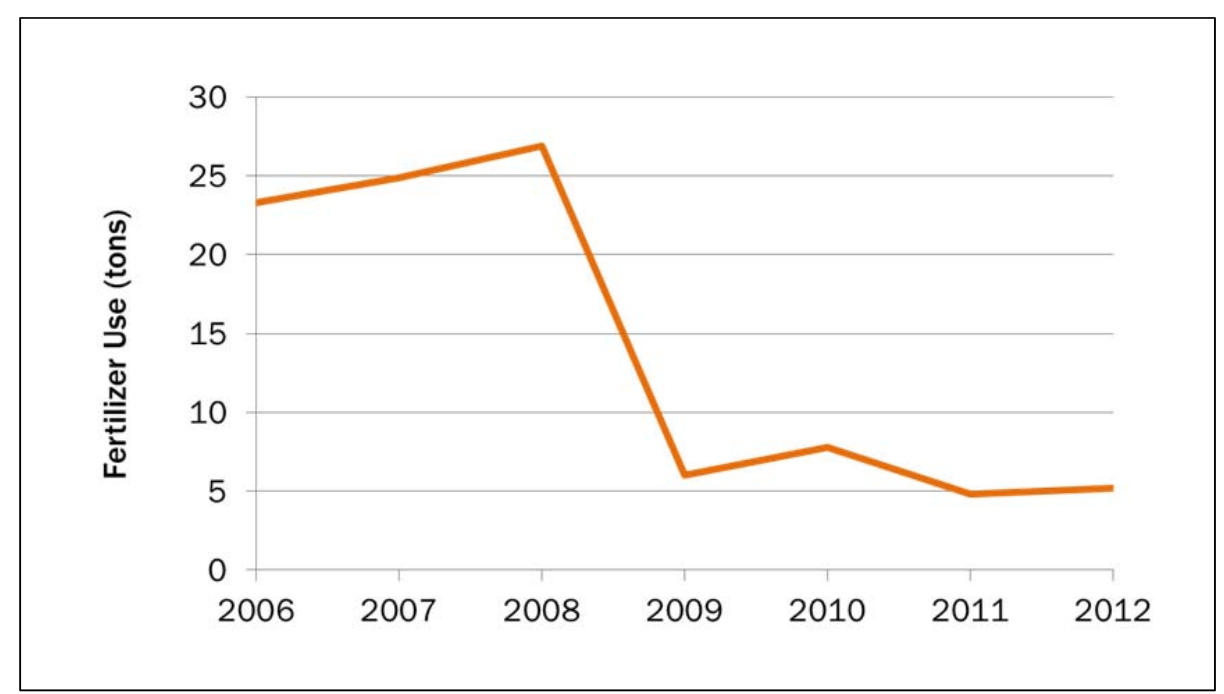

Note: 1 ton $=0.9$ metric ton

These concerns were addressed proactively through transition plans with longer crop rotations, including several years of grass and legume mixtures grown as hay and/or pasture in between corn crops. This was intended to suppress populations of annual weeds like pigweed, lambsquarters, and velvet leaf and allow time for soil organic nitrogen to accumulate from legume fixation. It was also essential for soil fertility since composted manure would not be available with the elimination of confined livestock feeding. In order to accommodate these longer rotations the amount of acreage dedicated to corn, the most inputintensive crop, was reduced. This was accomplished by gradually reducing the size of the livestock herds and discontinuing feeding corn to ruminants (described in the next section). Cattle grazing and well-timed hay harvests were used to combat Johnsongrass, a perennial plant that had been difficult to manage even with conventional herbicides.

In 2007 the farm maintained about 12 acres (4.9 ha) of certified organic land. In 2008, following the planning and visioning workshop, another 62 acres (25 ha) were put under organic transition. In 2009, another 24 (9.8 ha) acres were added, for a total of 98 acres (40 ha) (figure 2). In order to accomplish this conversion in a manner that minimized risk and potential disruption to the farm, the new organically managed land was used mostly for hay production and cattle grazing during the three-year transition period. Most of the corn production was restricted to conventionally managed land where fertilizers and herbicides could continue to be used. Small plantings of corn within the organic acreage validated our concerns about yield losses. The organic corn generally yielded 20-30 percent less 
than the conventional corn. It should be pointed out that no composted manure was applied to this corn only green manure cover crops - since the farm was also phasing out all confined feeding, resulting in less manure accumulation. But other anticipated changes also occurred that were more desirable. By discontinuing all synthetic fertilizer use on organic land and reducing it on the conventional land when possible (particularly pastureland), the farm was able to reduce its total fertilizer use from about 25 tons (22.7 metric tons) per year to less than 8 tons $(7.3$ metric tons) per year (figure 3). This generated an annual savings of over US\$10,000 (figure 4). Similarly, though less dramatically, annual herbicide expenses primarily for preemergent and postemergent herbicides for corn - dropped by about 30 percent.

Segregation of fuel consumption according to use was not possible because the farm's diesel tractors might be used for multiple tasks each day, such as soil preparation, planting, spraying, cultivating, mowing, harvesting, and transporting hay and livestock. In addition, the farm manager's truck, used by students for a variety of tasks, and the combine harvester operated on diesel. We expected a possible increase in diesel consumption with organic row-crop production as a result of more passes over the field for ground

Note: 1 gallon $=3.8$ liters

\section{Figure 4. Fertilizer Expenses (US\$) on the Berea College Student Farm, 2006-2012}

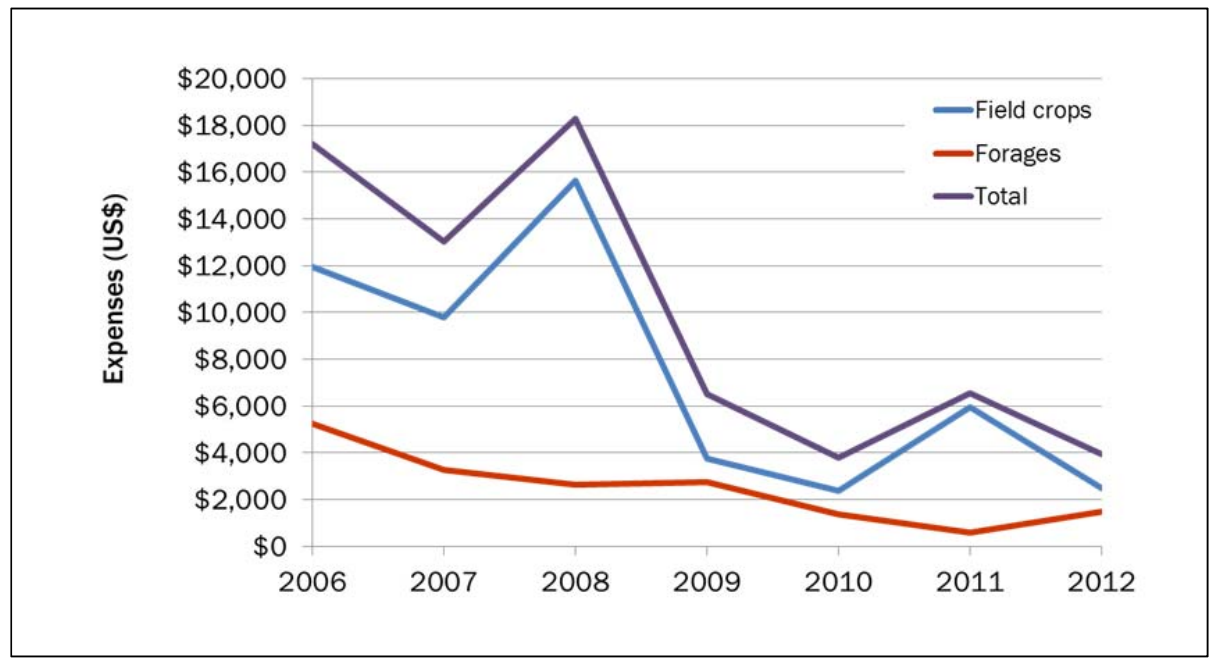

Figure 5. Fuel Use on the Berea College Student Farm, 2006-2012

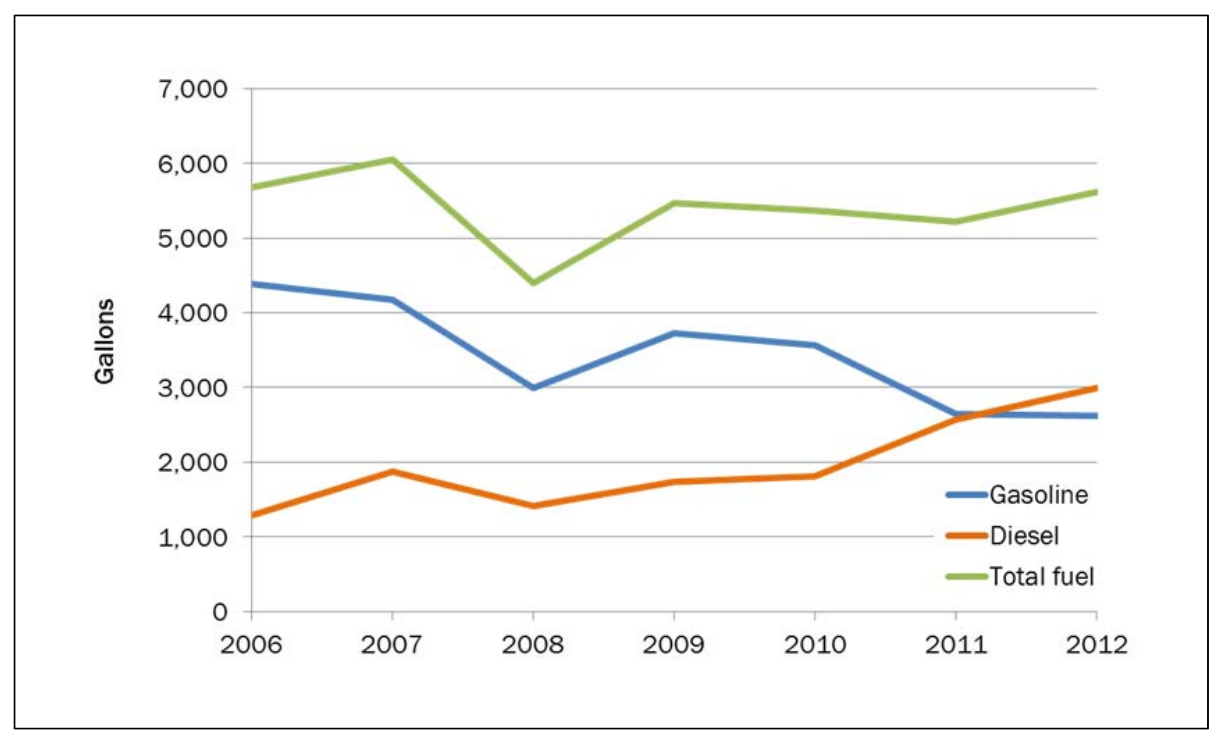

preparation and cultivation. In fact, diesel consumption on the farm did increase over the transition period (figure 5), and was largely accounted for by the greater use of tractors in the horticultural enterprise, replacing smaller gasoline-powered rototillers. Another important factor driving up diesel use was the more frequent use of the farm manager's truck for delivering livestock to the custom meat processor. Student travel in vans between campus and the farm, which accounted 
for a significant fraction of gasoline consumption, did not change. Overall, total fuel consumption remained steady, although use of gasoline declined and diesel increased during the transition (figure 5).

\section{Transition to Low-Input Livestock Production}

Changes to the livestock enterprises were aimed at addressing concerns about economic performance, environmental impact, and animal welfare. The farm's economic viability was highly dependent on the performance of the cattle and hog enterprises, which used 90 percent of the farm's land resources (table 2) and accounted for about 80 percent of the operating budget. And though these animal enterprises generated over 80 percent of the gross revenue for the farm, their dependence on purchased inputs, particularly feedstuffs, crop-fertilizers, and pharmaceuticals, as well as the generally low and unpredictable commodity prices they earned, made the entire farm financially vulnerable as these enterprises struggled to generate a positive cash flow at any given time. A valid and troubling question was raised: If the farm's livestock production systems were modeled on accepted conventional practices based on the most up-to-date technical information from universities and cooperative extension and yet the financial performance was marginal at best and likely unsustainable under real

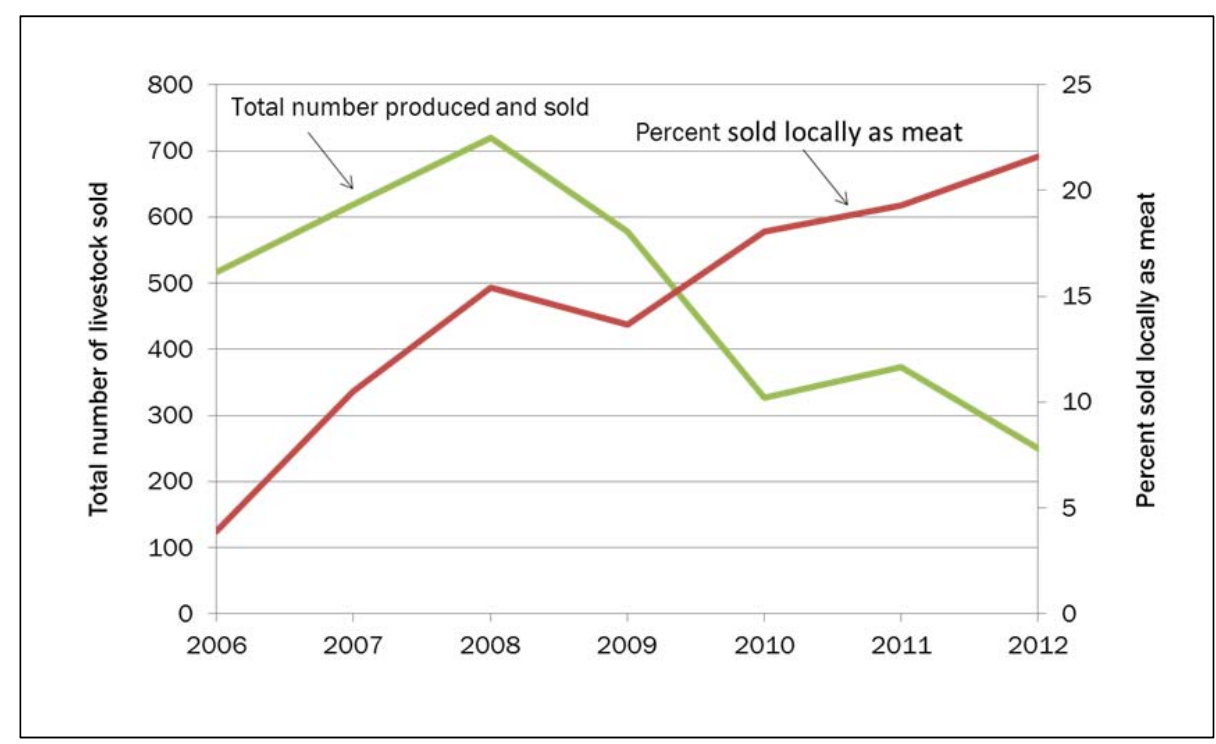

\section{Figure 6. Number of Livestock (Beef Cattle, Hogs, Sheep, and Goats)}

market conditions, what was the farm teaching students? While it might be argued that this was an economy-of-scale issue, the farm's newly defined mission was toward the small to medium-sized farms of the region. In this context the farm was really meeting neither of its goals for livestock production.

Specific concerns about the livestock enterprises prior to the farm's transition included the possible environmental and human-health effects associated with the continuous use of subtherapeutic antibiotics in the hog feed and the potential evolution of antibiotic resistance in pathogens (Anderson, Nelson, Rossiter, \& Angulo, 2003; Kumar, Gupta, Chander, \& Singh, 2005; Mathew, Beckmann, \& Saxton, 2001; McEwen \& FedorkaCray, 2002); the loss of nitrogen, an expensive input and environmental contaminant, from the hog-waste lagoons (Hatfield, Brumm, \& Melvin, 1998; Osterberg \& Wallinga, 2004); and unnecessarily feeding ruminant species (cattle, sheep, and goats) corn and other human-edible grains (Smil, 2002; Steinfeld, Gerber, Wassenaar, Castel, Rosales, \& de Haan, 2006). Although these conditions represented those typically found in conventional agriculture, many in the group thought they also had negative consequences to the farm's workers, the surrounding community, and beyond. The concerns about animal welfare stemmed largely from the use of gestation crates and confinement (Honeyman, 2005), though they were not shared by all. And the infrastructural investment for an industrial hog production system was seen as beyond the reach of small to medium-sized farmers and therefore not relevant to the region.

To begin to address the issues raised, two major changes in livestock production were planned and implemented on the farm beginning in 2008: (1) a side-by-side 
feasibility comparison of hogs produced conventionally indoors to those produced outdoors; and (2) a phasing out of all grain-based feeds for the cattle, goats, and sheep. Both of these changes were expected to at least begin to address the environmental concerns and reduce the costs of production. And both were tied to a necessary gradual reduction in herd size for all livestock enterprises. Prior to these changes the farm had been producing and selling 500-700 head per year (400-500 hogs, 50-100 beef cattle, and 50-100 goats and sheep). By the end of the transition the number of livestock produced was reduced by 50 percent (figure 6 ). The sheep were phased out by 2009 due to frequent health problems (intestinal parasites and foot rot) and losses to coyotes. A small goat herd was retained through new genetics for better suitability to a forage-only diet and to address similar health problems. The Boer goat herd was therefore replaced with Spanish x Kiko crosses.

The hog-system comparison was intended to examine the possible negative consequences of outdoor production before committing to a complete transition. In particular, there was concern over piglet mortality, feed-use efficiency and costs, and risk to student workers from defensive sows. The trial, established in September and October 2008, included nine sows outside and 13 sows under indoor confinement. The sows outside were provided with simple hoop structures and deep straw bedding for shelter. A cohort of 240 pigs was tracked from birth to finishing beginning in spring 2009. Upon finding that mortality rates, weight gain, and feed-use efficiency were comparable and that protocols adequately addressed student-worker safety, concerns were allayed and the last farrowing in gestation crates took place in spring 2009.

The newly established outdoor system incorporated Yorkshire, Berkshire, and Large Black genetics with some Duroc and Tamworth. The sows farrowed twice per year - March/April and September/October — in metal hooped huts with deep bedding. Piglets were ear-notched for identification and the males were castrated but tails were left intact. The pigs were weaned at 7-9 weeks old and fed a ration produced from farm-grown conventional corn, purchased commercial soybean meal, and a vitamin/mineral premix with no animal byproducts. No subtherapeutic antibiotics were added. Fall-produced pigs were allowed to "hog down" standing corn crops and provided with a purchased protein/vitamin/mineral supplement. The spring-produced pigs were given access to forage such as clover, turnip, and fodder rape along with the corn-based, milled ration. Hog grazing was controlled with portable electric fencing to thoroughly utilize the forages but prevent excessive soil disturbance and erosion (figure 7). Finished

\section{Figure 7. Hogs Produced Outside on the Berea College Student Farm Using Portable Electric Fencing for Controlling Grazing and Rooting and Provided with Deep-Bedded Hoop Shelters}

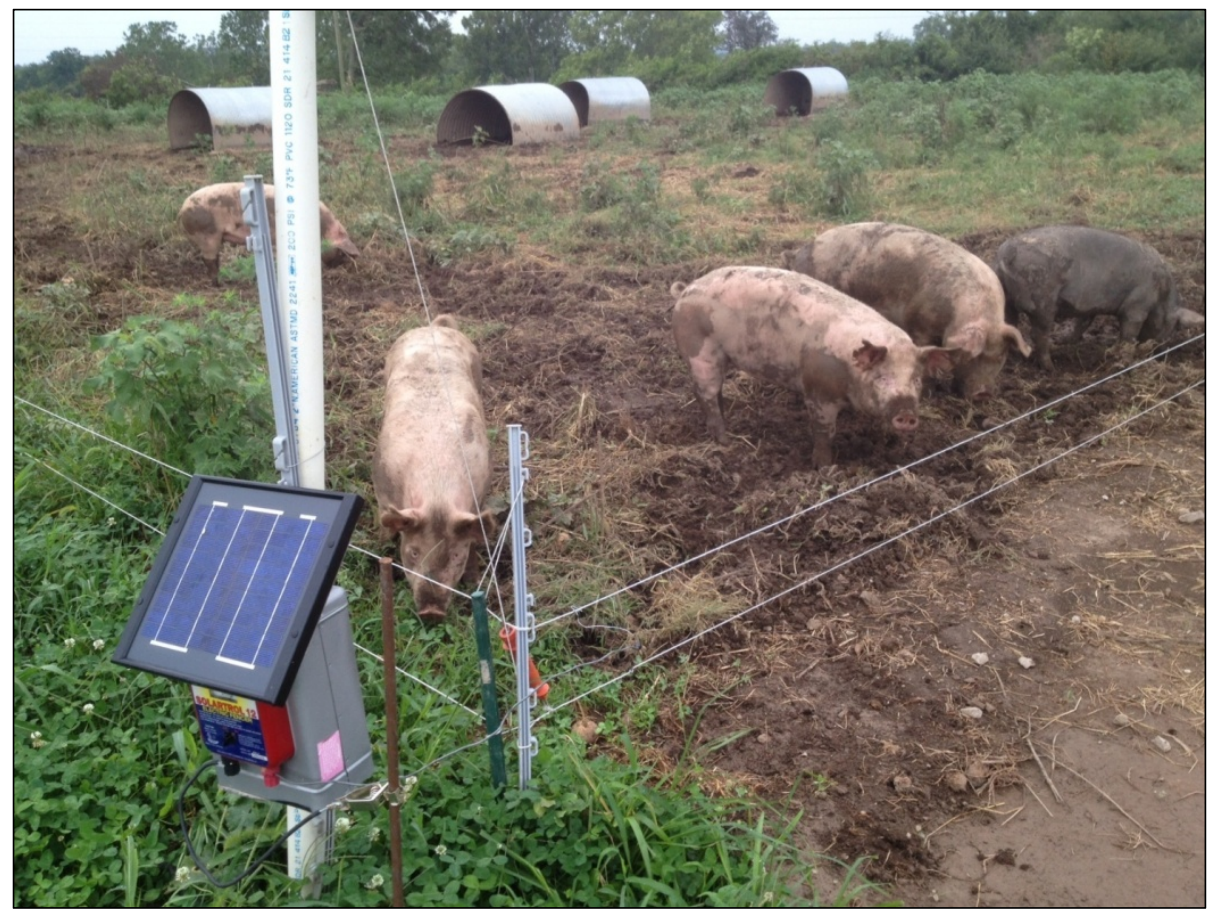


hogs were marketed and sold through several value chains listed here from most to least profitable:

(1) frozen meat cuts at the local farmers' market;

(2) custom-processed whole animals for the college dining hall; (3) live, directly from the farm to customers for home processing; and (4) live to a local meat processing and distribution company specializing in humanely and naturally produced products. This last option was facilitated by the farm's pursuit of an animal welfare certification (Animal Welfare Approved, n.d.) that was made possible by the new outdoor production system. These market pathways provided flexibility so that higher-value markets could be satisfied first and the remainder would go to lower-value markets. All were better options than selling to a large corporate meat-

\section{Table 3. Estimated Average Net Returns per Head (US\$) for Hogs and Beef Cattle Sold in 2011-2012 Through Different Market Pathways}

The return values are after accounting for production, processing, transportation, marketing, storage, and sales costs (including estimates of labor inputs). The first two represent pork and beef sales as frozen meat products while the other two pathways are sales of live animals.

\begin{tabular}{lcc}
\hline Market pathway & Hogs & \multicolumn{1}{c}{ Cattle } \\
\hline Retail cuts sold direct to consumer at farmers' market & $\$ 350$ & $\$ 1,250$ \\
\hline Custom-processed for college dining halla & $\$ 75$ & $\$ 55$ \\
\hline Live animals sold to specialty meat processor & $-\$ 50$ & $-\$ 75$ \\
\hline Stockyard auction or large corporate meatpackerb & $-\$ 100$ & $-\$ 85$ \\
\hline
\end{tabular}

a For cattle this is mostly cull-cows sold as hamburgers.

${ }^{\mathrm{b}}$ Estimated based on market prices since no hogs were sent through this pathway after 2010.

\section{Figure 8. Expenses (US\$) for Major Farm Inputs, 2006-2012}

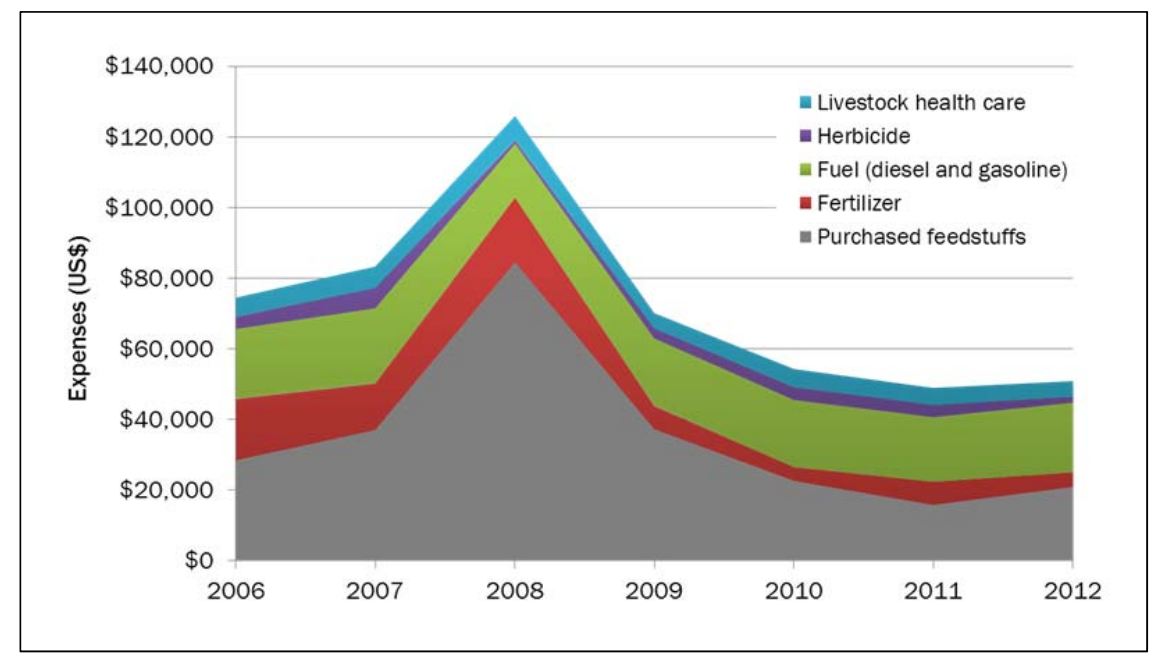

packer or via a stockyard auction, both of which were discontinued in 2009 (table 3).

Phasing out corn from the diets of the cattle herd, composed of Angus and Angus crosses with Gelbvieh and Simmental, took place relatively quickly and easily. Efforts were already underway to use the farm's pastureland more efficiently with a complete network of water delivery had to be in place and perimeter fencing needed to be repaired or built before this practice could fully replace the less intensively managed grazing that was used previously. Under the new management system cattle were rotated on mixed perennial pastures yearround and supplemented with hay as needed, particularly in winter. Grazing was managed intensively using portable electric fencing. The finished cattle were sold as (1) frozen retail meat cuts at the local farmers market; (2) custom-processed whole animals for the college dining hall; (3) live to the same local specialty meat processing and distribution company described above; or (4) at a stockyard auction (table 3). This range of marketing options provided needed flexibility for the enterprise.

In 2008 purchased livestock feed required an expenditure equivalent to 44 percent of the farm's gross revenue (figure 8). By 2011 and 2012 purchased feed costs had decreased by over 75 percent, accounting for only 14 percent of the farm's input costs (table 4), and were equivalent to only 10 percent of the farm's gross revenue (figure 8). This substantial reduction in off-farm feed inputs was accomplished largely by reducing herd sizes to bring them in line with the farm's feed-crop production 
capacity. Despite this, gross income was maintained during this time by generating more gross revenue per head through value-added market pathways (table 4). In 2006 only 4 percent of the animals were sold locally as meat, but by 2012 this figure had increased to 22 percent (figure 6). Most animals were still being sold at a loss, but when all costs were accounted for the increasing percentage sold as meat carried the livestock enterprises financially.

Total livestock costs declined only slightly during the transition period despite moderate to substantial reductions in herd size (figure 6), purchased feed expenditures (figure 7), and to a lesser extent, health-care costs, because of the additional costs for processing, transporting, storing, marketing, and selling more meat. But these additional costs were a necessary investment to capture more of the potential value per animal produced and sold.

\section{Localization of Marketing and Sales}

The farm's transition to organic crop and lowinput livestock production may not have succeeded had it not been for new local and regional markets that emerged concurrently. Prior to the transition, sales of certified organic fresh produce had steadily increased but still accounted for less than 15 percent of the farm's total gross revenue, which was still generated largely through sales of conventionally produced livestock. As the farm took on a more active and year-round role at the local farmers market, its sales of produce, and to a lesser extent meat, continued to rise. But by 2009 , farmersmarket sales leveled off and even began to decline. The farm had a loyal customer base that valued the products, but there were also some town-gown tensions as some producers blamed the student farm's success for decreases in their sales. Some customers began to avoid the student farm as a result. In actuality these slumping sales coincided with the start of the Great
Recession of 2008-2009, and sales for all producers, including the student farm, were suffering. Fortunately, other markets opened up.

After several years of dialogue and negotiations with the college's food service contractor, Sodexo, Inc., the farm began to sell a modest amount of meat and produce to the dining hall for student consumption in 2006. It had been several decades since any food from the student farm had been purchased by the dining hall. This new interest in buying a limited amount of the farm's products was partly an effort by Sodexo to appease the college administration and ensure contract renewal, but it was also a test of the farm's capacity to supply products reliably, consistently, and economically on a much larger scale than it had been recently accustomed. (Berea College has about 1,600 students, with 80 percent of them eating in the dining hall.) During a three-year trial period (2006-09) the farm adjusted its production schedules to better suit the dining hall's demand and improve the farm's organization, efficiency, and communication with the dining hall. The dining hall's staff also became more accustomed to handling seasonal variations in product availability. A solid and trusting relationship between parties developed and a sharp increase in purchases began in 2010 (figure 9). This new outlet for the farm's products helped counter the stagnating farmersmarket sales, particularly for meat. And though the net margins (including estimated labor costs) on custom-processed livestock for the dining hall were
Figure 9. Student Farm Sales (US\$) to the College Dining Hall, 2007-2012

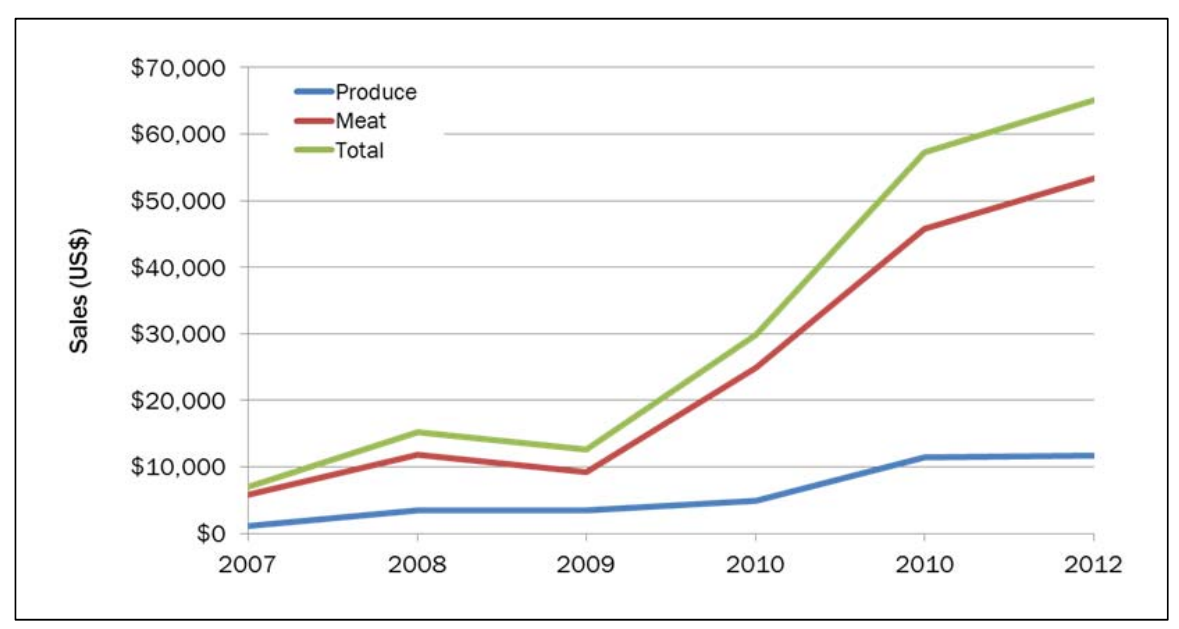


not nearly as high as those sold at the farmers market, they were much better than those sold live (table 3).

Another marketing and sales option emerged in 2010 with the opening of Marksbury Farm Market less than 30 miles $(48 \mathrm{~km})$ from Berea, a specialty meat processing and marketing company with a stated commitment to buying livestock only from local farmers using "sustainable, humane and natural production methods." The company paid a small premium over commodity prices and offered custom processing services much closer to the

Figure 10. Farm Annual Net Cash Flow (US\$), 2007-2012

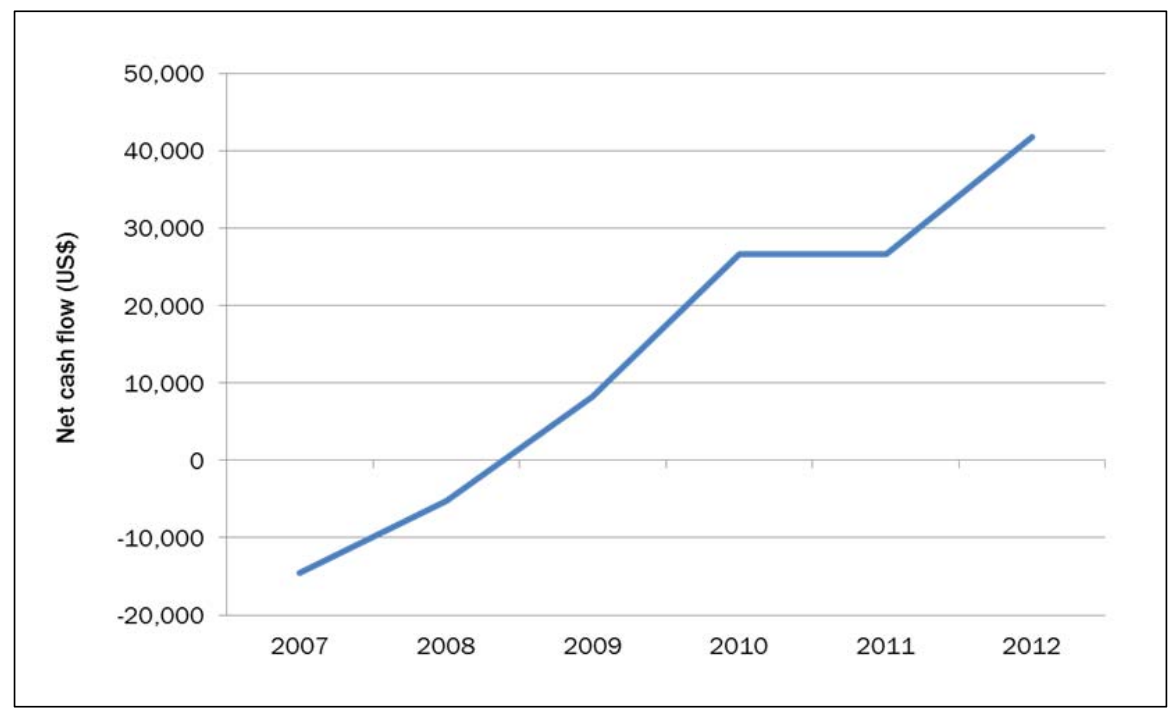

Figure 11. Farm Gross Income and Expenditures (US\$) for Purchased Feed in Dollars and as a Percentage of Annual Gross Income, 2006-2012

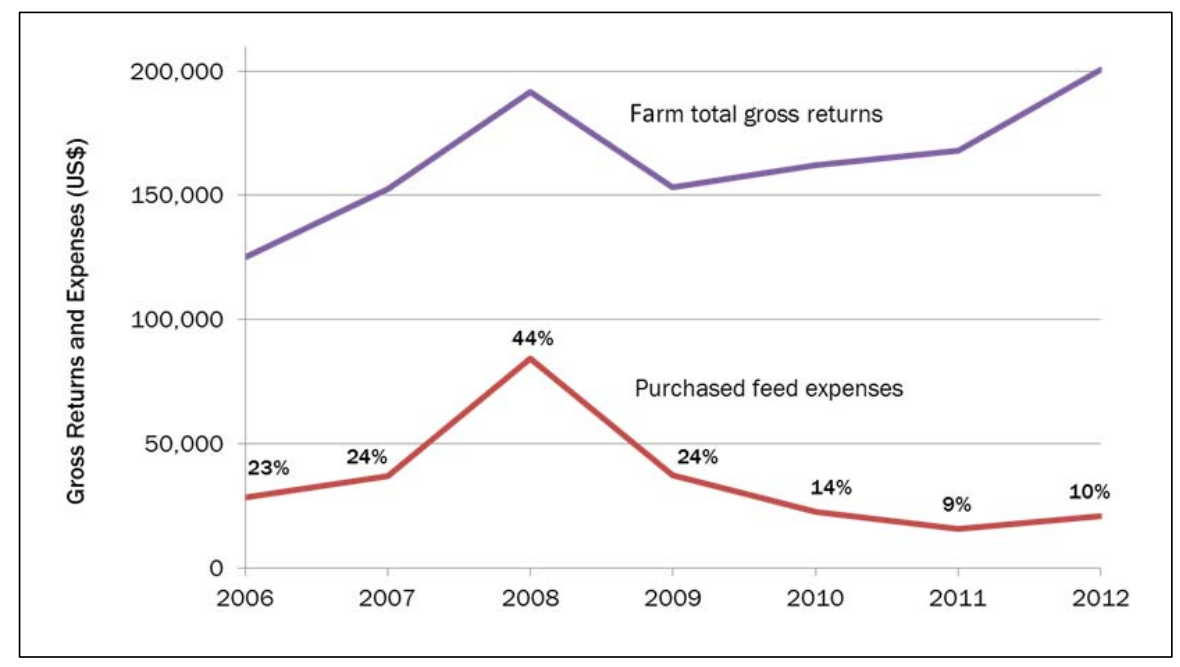

farm than other USDA-inspected processors. With certification from Animal Welfare Approved established for cattle in 2010 and for hogs in 2011, the farm finally had an alternative to the conventional commodity markets and auctions. However, although this provided a better option it was still only an outlet for surplus animals after the preferred retail and custom meat markets, as it was still not profitable (table 3 ).

The net effect of this combination of interrelated changes on the farm's overall financial performance was positive and substantial. Over the six-year period from 2007 to 2012 the annual net cash flow improved by over US $\$ 50,000$ (figure 10). This was accomplished largely by expanding organic crop production, reducing livestock herd sizes and their associated costs, focusing on the efficient use of appropriate feeds produced on-farm rather than purchased feedstuffs (figure 11), adding value through processing and adopting production practices that permitted third-party certifications, and finding new markets, which typically offered higher prices.

The initiatives had a synergistic effect in buffering the farm financially when some individual enterprises suffered losses due to mistakes, miscalculations, or unanticipated events (like flooded fields, drought, and changing markets) or when expensive investments were required. The horticulture enterprise actually carried the farm financially during the early years of the transitional period (2008-09). It 
increased output using season-extension techniques to produce nearly year-round, expanded the range of products offered to include human-edible grains and pulses, and improved yields and quality to cover the losses of the livestock enterprises. During the transition period the horticulture enterprise expanded its footprint from just over 1 percent to nearly 3 percent of the available farmland as the livestock land requirements declined. Herd-size reductions for all three livestock enterprises and the elimination of corn from the rations of the ruminants reduced the need for field corn, both farm-produced and purchased. This allowed the farm to put most of the transitional land into forages to build soil fertility, manage weeds, and minimize the risks of producing corn organically prior to certification.

Likewise, the changes to the hog and cattle operations not only reduced pressure on the farm's field-crop operation, but also created the opportunity for an animal welfare certification that granted access to alternative markets. The shift toward direct marketing of meat instead of live animals and the new specialty market for live animals helped to maintain a nearly stable income stream even as herd sizes were reduced. Some of the savings from reduced feed purchases and animal health-care expenses were tempered by new processing and transportation costs as more livestock were processed into meat, marketed, stored, and eventually sold. But this investment made it possible to generate nearly as much gross income with only 250 animals as was previously made selling 700 head, mostly as live animals.

\section{Lessons Learned}

This case study demonstrates the high degree of interdependence among these three initiatives aimed at improving the farm's sustainability (table 1). Though each initiative contributed to reducing the farm's reliance on off-farm inputs and improving its overall financial performance, the implementation of each was dependent on the other two occurring simultaneously. The total amount of farmland used and labor invested remained steady while the allocation of land and labor to each enterprise changed to accommodate to new practices. The transition to organic crop production resulted in an expected reduction in agrochemical use and expenses, higher prices for crop products in the market, and an improvement to the financial performance of the whole-farm system. The implementation of the new organic crop rotation required that the acreage devoted to corn each year be reduced and partially replaced with forages, which are easier to grow without fertilizers and herbicides and which improve soil quality. Decreasing the livestock herd sizes and transitioning the cattle from grain- to grass-finishing reduced the farm's need for corn. With fewer animals being produced, the farm had to seek ways to generate more revenue per animal and did so by selling more meat to local markets and fewer live animals through less lucrative commodity markets. Fewer livestock also allowed for an expansion of acreage used for certified organic horticultural and field crops, which generated greater returns per acre than hogs or cattle.

Gross revenue per acre from horticultural production, which was entirely under organic management during the five-year period, was five times greater than that of the hogs and 20 times greater than for ruminants (table 2). If land is considered the most limiting resource of the farm, as it often is on small farms, using it for horticulture makes sense financially. Horticultural products were only sold locally and there are advantages to the shorter product value chains for the farm, local wholesale buyers, and consumers. Less time between harvest and consumption should result in less waste and fresher products, which are not only more nutritious but also more appealing to eat (Kader, 2008; Rickman, Barrett, \& Bruhn, 2007).

\section{Remaining Questions}

Consistent information is lacking on the relative environmental costs of different types of meat production systems. It is well established that most meats, and especially beef, require greater inputs of natural resources and generate more polluting emissions per unit of caloric energy and protein than plant-based foods (Hamerschlag, 2011; Pimentel \& Pimentel, 2007; Smil, 2002). There is less agreement, however, on the relative pros and cons of different livestock production systems. Some researchers have reported a variety of envi- 
ronmental benefits from low-input and organic livestock production systems over their conventional counterparts (Casey \& Holden, 2006; Haas, Wetterich, \& Köpke, 2001). These include reductions in energy consumption per acre, energy use per unit of product, greenhouse gas emissions, and potential water and air pollution. But recent lifecycle assessments for beef (Pelletier, Pirog, \& Rasmussen, 2010) and pork (Pelletier, Lammers, Stender, \& Pirog, 2010) in the north-central U.S. suggest that grass-based and organic livestock production systems have no advantages or may even be worse than conventional systems in energy use, greenhouse gas emissions, eutrophication potential, and ecological footprint. In particular, Pelletier, Pirog and Rasmussen report that slower growth rates for cattle on pasture extend the production period and consequently result in more methane production. For hogs raised outside, lower feed efficiencies and fewer piglets produced per sow were assumed, resulting in lower efficiency rates and an inferior environmental performance relative to confinement hogs.

Gurian-Sherman (2011), as well as Pelletier and colleagues, caution against broad generalizations from life-cycle assessments like these due to the assumed values for production rates, conversion efficiencies, pollution emissions, and carbon sequestration rates - all of which can fall within wide potential ranges. Variations in local and regional conditions, including land and soil characteristics, climate, and pasture composition and productivity may have important effects on calculated outcomes. Further, there may be relevant management differences within a given type of production system. For example, outdoor hog production on the Berea College student farm included moving the hog herd through standing cornfields in a controlled manner using portable electric fencing. This eliminated a number of steps that were previously part of the conventional indoor confinement system, including combine harvesting, drying, milling, and transporting corn, as well as pumping the waste lagoons to adjacent pastures. The absence of these activities in the alternative system reduced production costs and likely reduced energy use and the pollution potential relative to the former confinement system.
While there is still much to learn about the environmental trade-offs of alternative livestock systems, there is somewhat more agreement on the environmental trade-offs of organic and conventional crop production. Gomiero et al. (2011) conducted a thorough literature review comparing organic and conventional cropping systems and reported that organic systems offer numerous advantages with respect to soil quality, protection of water and biodiversity, and efficient use of nonrenewable resources. But lower crop productivity per acre is typical in organic systems, particularly for crops with high nitrogen demands, like corn. Lynch, MacRae, \& Martin (2011) also conducted a comprehensive literature review and concluded that there was strong evidence favoring organic over conventional crop production for reducing nonrenewable energy inputs and improving energy efficiency per acre and per unit of product. But the literature was less definitive about greenhouse gas emissions. Similarly, Venkat (2012) used life-cycle assessments to compare greenhouse gas emissions for 12 crops produced organically and conventionally in California and found that in some cases organic performed better and in others conventional production was superior, largely due to higher conventional yields.

Future considerations for the Berea College student farm should weigh the benefits of continued expansion of organic annual horticultural crops against the risks of annually disturbing the farm's vulnerable low-quality land, with its rolling topography, shallow soils, and poor drainage. The most productive and environmentally sound use for most of this land, at least when considering soil and water quality, may be grass-based cattle production. Improved understanding of the environmental and/or community-health impacts of the farm's enterprises will undoubtedly be taken into account, but market demand will drive future decision-making because farm financial viability is necessary before externalities, like off-farm environmental degradation, can be addressed.

\section{Conclusions}

The goals of the three interdependent initiatives were to address observed or deduced deficiencies that compromised the sustainability of the farm, 
particularly in the areas of environmental stewardship, economic viability and stability, and livestock welfare (table 1). The students, staff, and faculty involved brought different perspectives, expertise and concerns to the conversation, but all were motivated to improve the college's primary experiential laboratory for teaching and learning agriculture. All of the stakeholders who helped develop and implement the initiatives were guided by the two overarching goals for the farm - practical educational laboratory and model of sustainability - and informed by current scientific literature as well as actual farm experiences. The three initiatives could be viewed as conceptually simple, but the practical implementation required many changes to daily, routine activities that were collectively challenging and risky because of possible unknowns from within (e.g., poor crop production, livestock illness, and technological or management failures) and outside (e.g., extreme weather events, changes in market demand and prices) of the farm. Any changes made to one enterprise on this diversified farm inevitably affected other parts of the farm, a reality that is often not addressed in smallscale, controlled, replicated plot studies.

The measurable outcomes according to the partial-budget analysis and use of purchased inputs, like feedstuffs and synthetic fertilizers, indicate that improvements were achieved in the farm's operations. But environmental outcomes, which are still largely externalities, could not be directly measured. Instead, we must make inferences from the literature. It is clear that the posttransition farm used fewer nonrenewable material inputs in crop production, like fertilizers and herbicides, but some questions remain about the net effects of the livestock initiative, particularly regarding greenhousegas emissions. The livestock initiative was also aimed at improving animal welfare - including maintaining good animal health, preventing suffering, and accommodating natural behaviors and this outcome is problematic to document or quantify. The posttransition farm sold more products locally and, by adding value through processing (mainly by converting livestock into meat), was able to generate the same or greater gross revenue with fewer animals and lower material costs. As a result of the new crop and livestock manage- ment practices the farm gained access to new markets, which often offered premiums for third-party certifications (USDA certified organic and Animal Welfare Approved). As reliable information becomes available and consensus builds in the agriculture community, externalities should be factored into the analysis to more thoroughly understand the broader economic, environmental and social costs and benefits of this transition.

\section{Acknowledgements}

The author acknowledges the contributions and teamwork of the entire farm advisory board during the study period, including past and present members who played critical roles during the farm's transition period. This includes Bob Harned, Jamie Rowse, Matt Wilson, Derek Law, Andrew Oles, Janet Meyer, Jessa Turner, and Michael Panciera. Thanks also to the many dozens of students who were essential in the running the farm each day and without whom there would be no farm.

\section{References}

Anderson, A. D., Nelson, J. M., Rossiter, S., \& Angulo, F. J. (2003). Public health consequences of use of antimicrobial agents in food animals in the United States. Microbial Drug Resistance, 9(4), 373-379. http://dx.doi.org/10.1089/107662903322762815

Animal Welfare Approved. (n.d.). Standards. Available at http://www.animalwelfareapproved.org/standards

Badgley, C., Moghtader, J., Quintero, E., Zakem, E., Chappell, M. J., Avilés-Vázquez,...Perfecto, I. (2007). Organic agriculture and the global food supply. Renewable Agriculture and Food Systems, 22(2), 86-108. http://dx.doi.org/10.1017/S1742170507001640

Casey, J. W., \& Holden, N. M. (2006). Greenhouse gas emissions from conventional, agri-environmental scheme, and organic Irish suckler-beef units. Journal of Environmental Quality, 35(1), 231-239. http://dx.doi.org/10.2134/jeq2005.0121

Cavigelli, M. A., Teasdale, J. R., \& Conklin, A. E. (2008). Long-term agronomic performance of organic and conventional field crops in the mid-Atlantic region. Agronomy Journal, 100(3), 785-794. http://dx.doi.org/10.2134/agronj2006.0373 
Clark, S. (2011). Berea College. In L. Sayre \& S. Clark (Eds.), Fields of learning: The student farm movement in North America (pp. 31-50). Lexington, Kentucky: University Press of Kentucky. Available at http://muse.jhu.edu/books/9780813133959

Clark, S., \& Cavigelli, M. (2005). College composting program matures. BioCycle, 46(7), 35-38. Retrieved from http://www.biocycle.net

Clark, S., Klonsky, K., Livingston, P., \& Temple, S. (1999). Crop-yield and economic comparisons of organic, low-input, and conventional farming systems in California's Sacramento Valley. American Journal of Alternative Agriculture, 14(3), 109-121. http://dx.doi.org/10.1017/S0889189300008225

Gomiero, T., Pimentel, D., \& Paoletti, M. G. (2011). Environmental impact of different agricultural management practices: Conventional vs. organic agriculture. Critical Reviews in Plant Sciences, 30(1-2), 95-124. http://dx.doi.org/10.1080/07352689.2011.554355

Gurian-Sherman, D. (2011). Raising the steaks: Global warming and pasture-raised beefproduction in the United States. Cambridge, Massachusetts: Union of Concerned Scientists. Retrieved from http://www.ucsusa.org/assets/documents/ food and agriculture/global-warming-and-beefproduction-report.pdf

Haas, G., Wetterich, F., \& Köpke, U. (2001). Comparing intensive, extensified and organic grassland farming in southern Germany by process life cycle assessment. Agriculture, Ecosystems \& Environment, 83(1-2), 43-53. http://dx.doi.org/10.1016/S01678809(00)00160-2

Hamerschlag, K. (2011). Meat eater's guide to climate change+ health. Environmental Working Group. Retrieved from http://static.ewg.org/reports/ 2011/meateaters/pdf/report ewg meat eaters guide to health and climate 2011.pdf

Hatfield, J. L., Brumm, M. C., \& Melvin, S. W. (1998). Swine manure management. In R. J. Wright, W. D. Kemper, P. D. Millner, J. F. Power, \& R. F. Korcak (Eds.), Agricultural uses of municipal, animal, and industrial byproducts (Conservation Research Report No. 44, pp. 78-90). Washington, D.C.: U.S. Department of Agriculture, Agricultural Research Service. Available at http://www.ars.usda.gov/is/ np/agbyproducts/agbyintro.htm

Holder, T. H. (2011). A model-based determination of human carrying capacity in Kentucky's ecoregions (Unpublished master's capstone project). Kentucky State University. Available at http://mes.kysu.edu/graduates.html

Honeyman, M. S. (2005). Extensive bedded indoor and outdoor pig production systems in USA: Current trends and effects on animal care and product quality. Livestock Production Science, 94(1-2), 15-24. http://dx.doi.org/10.1016/j.livprodsci.2004.11.029

Jeavons, J. C. (2001). Biointensive sustainable minifarming: I. The challenge. Journal of Sustainable Agriculture, 19(2), 49-63. http://dx.doi.org/10.1300/J064v19n02 06

Kader, A. A. (2008). Flavor quality of fruits and vegetables. Journal of the Science of Food and Agriculture, 88(11), 1863-1868. http://dx.doi.org/10.1002/jsfa.3293

Kumar, K., Gupta, S. C., Chander, Y., \& Singh, A. K. (2005). Antibiotic use in agriculture and its impact on the terrestrial environment. Advances in Agronomy, 87, 1-54. http://dx.doi.org/10.1016/S00652113(05)87001-4

Lynch, D. H., MacRae, R., \& Martin, R. C. (2011). The carbon and global warming potential impacts of organic farming: Does it have a significant role in an energy constrained world? Sustainability, 3(2), 322-362. http://dx.doi.org/10.3390/su3020322

Mathew, A. G., Beckmann, M. A., \& Saxton, A. M. (2001). A comparison of antibiotic resistance in bacteria isolated from swine herds in which antibiotics were used or excluded. Journal of Swine Health and Production, 9(3), 125-129. Retrieved from https://aasv.org/shap/issues/v9n3/v9n3p125.pdf

McEwen, S. A., \& Fedorka-Cray, P. J. (2002). Antimicrobial use and resistance in animals. Clinical Infectious Diseases, 34(Supplement 3), S93-S106. http://dx.doi.org/10.1086/340246

Osterberg, D., \& Wallinga, D. (2004). Addressing externalities from swine production to reduce public health and environmental impacts. American Journal of Public Health, 94(10), 1703-1708. http://dx.doi.org/10.2105/AJPH.94.10.1703

Pelletier, N., Lammers, P., Stender, D., \& Pirog, R. (2010). Life cycle assessment of high- and lowprofitability commodity and deep-bedded niche swine production systems in the Upper Midwestern United States. Agricultural Systems, 103(9), 599-608. http://dx.doi.org/10.1016/j.agsy.2010.07.001 
Pelletier, N., Pirog, R., \& Rasmussen, R. (2010). Comparative life cycle environmental impacts of three beef production strategies in the Upper Midwestern United States. Agricultural Systems, 103(6), 380-389. http://dx.doi.org/10.1016/j.agsy.2010.03.009

Pimentel, D., Hepperly, P., Hanson, J., Douds, D., \& Seidel, R. (2005). Environmental, energetic, and economic comparisons of organic and conventional farming systems. BioScience, 55(7), 573-582. http://dx.doi.org/10.1641/0006-3568(2005) 055\%5B0573:EEAECO \%5D2.0.CO;2

Pimentel, D., \& Pimentel, M. H. (Eds.). (2007). Food, energy, and society (Third ed.). CRC Press. http://dx.doi.org/10.1201/9781420046687

Rickman, J. C., Barrett, D. M., \& Bruhn, C. M. (2007). Nutritional comparison of fresh, frozen and canned fruits and vegetables. Part 1. Vitamins C and B and phenolic compounds. Journal of the Science of Food and Agriculture, 87(6), 930-944. http://dx.doi.org/10.1002/jsfa.2825

Roth, S., \& Hyde, J. (2002). Partial budgeting for agricultural businesses. University Park, Pennsylvania: The Pennsylvania State University. Retrieved from http://agmarketing.extension. psu.edu/Business/PDFs/PartlBudgetAgBus.pdf

Sayre, L., \& Clark, S. (Eds.). (2011). Fields of learning: The student farm movement in North America. Lexington,
Kentucky: University Press of Kentucky. Available at http://muse.jhu.edu/books/9780813133959

Smil, V. (2002). Eating meat: Evolution, patterns, and consequences. Population and Development Review, 28(4), 599-639. http://dx.doi.org/10.1111/j.17284457.2002.00599.x

Steinfeld, H., Gerber, P., Wassenaar, T., Castel, V., Rosales, M., \& de Haan, C. (2006). Livestock's long shadow: Environmental issues and options. Rome: Food and Agriculture Organization of the United Nations. Retrieved from ftp://ftp.fao.org/docrep/ fao/010/a0701e/a0701e00.pdf

U.S. Census Bureau. (n.d.). State and county quickefacts: Berea (city), Kentucky. Retrieved from http://quickfacts.census.gov/qfd/states/21/ 2105842.html

U.S. Department of Agriculture, National Agricultural Statistics Service [NASS]. (2008). Kentucky agricultural facts. Retrieved from http://www.nass.usda.gov/Statistics by State/ Kentucky/Publications/Pamphlets/kyfacts.pdf

Venkat, K. (2012). Comparison of twelve organic and conventional farming systems: A life cycle greenhouse gas emissions perspective. Journal of Sustainable Agriculture, 36(6), 620-649. http://dx.doi.org/10.1080/10440046.2012.672378 